Bioscientia Medicina: Journal of Biomedicine \&

Translational Research

Journal Homepage: www.bioscmed.com

\title{
Analysis of the Electronic Implementation of A Malaria Surveillance In formation System (E-SISMAL) in the Lahat District
}

Eni Nuraini ${ }^{1}$, Hamzah Hasyim ${ }^{2,3^{\star}}$, Haerawati Idris ${ }^{2}$, Ahmad Ghiffari ${ }^{3,4}$, Chairil Anwar ${ }^{5,6}$

${ }^{1}$ Master Program of Public Health, Faculty of Public Health, Universitas Sriwijaya, Palembang, Indonesia

2 Faculty of Public Health, Universitas Sriwijaya, Palembang, Indonesia

3 Faculty of Environment, Graduate School, Universitas Sriwijaya, Palembang, Indonesia

${ }^{4}$ Faculty of Medicine, Universitas Muhammadiyah Palembang, Palembang, Indonesia

${ }^{5}$ Faculty of Medicine, Sriwijaya University, Palembang, Indonesia

${ }^{6}$ Faculty of Environment, Sriwijaya University, Palembang, Indonesia

A R T I C L E I N F O

Keywords:

E-SISMAL

Malaria elimination

Malaria surveillance

Human resources

Telecommunications companies

*Corresponding author:

Hamzah Hasyim

E-mail address:

hamzah@fkm.unsri.ac.id

All authors have reviewed and approved the final version of the manuscript.

https://doi.org/10.32539/bsm.v5i11.419

\begin{abstract}
A B S T R A C T
Background: The requirement for malaria elimination to be recognized is to prove API lower than 1 per 1000 in the population, together with no indigenous case. Lahat Regency is an area of low-endemicity for malaria, where the target for elimination is projected for 2024. Since 2019, Lahat Regency has received socialization about ESISMAL, which was developed as a web-based basis to speed up the reporting process. However, there are still delays in reporting malaria on E-SISMAL. Methods: Descriptive research with a qualitative approach was designed. The study subjects were the malaria person in charge, the head of seven selected community health centers (Puskesmas) and the Lahat District Health Office. Primary data came from observation, focus group discussion (FGD) and in-depth interviews with eighteen informants selected by the purposive sampling method. Results: The available inputs are inadequate, such as the human resource education was not up to standard, the internet network was not smooth, and there were no guidelines on ESISMAL in the health centers. Malaria person in charge does not understand how to use E-SISMAL. In the process, there was the involvement of cross-sectoral and networked establishments. The output shows that the report indicators on E-SISMAL are not up to standard with less than $80 \%$. Conclusions: The use of E-SISMAL in the Lahat district has not been maximized. It has an impact on delays in reporting. It is recommended that training and practice of E-SISMAL occur to improve officers' ability through socialization and that the Lahat Health Office establishes partnerships with telecommunications companies to ensure the smooth running of the network. Developing specific guidelines on E-SISMAL and a mobile phone-based malaria surveillance information system to speed up the malaria reporting process
\end{abstract} in the Lahat district is also advisable.

\section{Introduction}

Since 2015 the United Nations has formulated the "Sustainable Development Goals" or SDGs. The SDGs contain 17 goals and 169 targets for the 2015-2030 implementation period. One of the goals is to create a world free of hunger and disease. Elimination of malaria is one way to create a world free from disease ${ }^{1}$. Malaria can be transmitted to anyone through the bite of a mosquito containing Plasmodium. Pregnant women who suffer from malaria have a higher mortality risk and give birth prematurely or give birth to babies with low birth weight 2 .
A malaria elimination certificate can be obtained if an area can prove its capacity. The territory must be free from local transmission (indigenous cases) in the last three years; the value of annual parasite incidence (API) less than 1\%; and there is a good system to ensure no re-infection of malaria cases ${ }^{3}$. The API value is calculated by dividing the number of confirmed malaria cases by the number of individuals at risk by $1000^{4}$. In 2019, nine districts in South Sumatra with low endemicity remained uncertified. By 2025, malaria in South Sumatra must be eliminated ${ }^{5}$. Lahat is one of the districts with low endemicity in South Sumatra 
province in 2019 and is targeted for malaria elimination by 20245 . The elimination stages proceed at the subdistrict, district, provincial and then central levels. The national target of the malaria elimination program is that all regions in Indonesia be free from malaria no later than $2030^{3}$.

The malaria information system (E-SISMAL) is an information system. A system is formed from several interrelated elements, namely input, process and output. E-SISMAL began to develop web-based in 2019 and has been socialized. Several studies have found that the use of electronic information systems in malaria surveillance reporting has various advantages, for example, shortening the time to submit reports from the basic level to the district level6; and establishing timely response management, which is very important for malaria elimination ${ }^{7}$ as well as enabling more accurate data and complete data to be recorded 8 .

Several studies on malaria surveillance have been carried out, but no studies specifically discuss using the E-SISMAL application in Indonesia. The Lahat district's achievement on malaria surveillance report indicators in 2019 was still below the target (an average of $37.62 \%$ ) of $80 \%$. E-SISMAL is an information system consisting of several interrelated elements, namely input, process and output 9 . This study aims to analyze E-SISMAL in the Lahat district based on input, process and output components.

\section{Methods}

This research is a descriptive study using a qualitative approach. The research was conducted from July to September 2021. The research subjects were the Lahat District Health Office and the community health centers (puskesmas) using the purposive sampling method, selecting informants with certain inclusion criteria. The criteria for selecting research subjects were health centers that had malaria cases in 2019, such as Bandar Jaya, Bunga Mas, Merapi 2, Nanjungan, Selawi and Senabing health centers. The respondents are the malaria person in charge, laboratory officers and the head of the community health centers.

The study variables are made up of inputs, processes, and outcomes. Inputs include human resources (HR), finance, infrastructure, and competencies. Data collection, compilation, analysis, and interpretation are all parts of the process. The result is the percentage of E-SISMAL report accuracy indicators that are correct. In this study, observation guidelines, FGD guidelines, and in-depth interviews were employed as research methodologies. Descriptive data analysis using thematic methods. The Universitas Sriwijaya Faculty of Public Health issued a Certificate of Research Ethics with number 179/UN9.FKM/TU.KKE/2021 in 2021.

\section{Results}

\section{Input}

The results showed that the Lahat District Health Office had one person managing the malaria program to collect routine malaria surveillance data. The malaria management officer had a master's degree in education and received E-SISMAL training in 2018 and 2019. The results of FGDs at seven selected community health centers showed that the number of malaria management officers was one person in each community health center. The program management officer had a Diploma in Nursing or Midwifery or was an Analyst. Some of these officers had dual duties, and some officers also doubled as laboratory personnel. So far, the officer has attended E-SISMAL training twice, in 2018 and 2019, but had not received training in 2020 or 2021.

The FGD and interviews found that the funding for surveillance was sourced from the Operational Assistance Fund (or BOK) of the Lahat District Health Office. The funds are used for transportation, epidemiological investigations $(\mathrm{PE})$ and monitoring of mosquito larvae. The flow of proposals for BOK funds starts from the community health centers submitting a Proposed Activity Plan to the Lahat District Health Office. The amount of funds obtained sometimes does not follow that proposed by the community health centers. Since currently, malaria cases are decreasing, the funds provided were sufficient.

Facilities at the Lahat district health office consisted of computers, electricity, malaria surveillance 
recording and reporting software, Electronic Malaria Surveillance Information System (E-SISMAL), malaria surveillance implementation manuals, and communication equipment. These facilities are adequate.

Health centers are equipped with a range of facilities such as laboratory equipment, reporting tools, and transportation services. The District Health Office provides the malaria examination equipment, such as rapid diagnostic tests and microscopes, and the reporting tools, such as report blanks, computers, printers, internet networks, electricity, and transportation equipment, to send physical reports to the District Health Office. These community health centers do not yet have a malaria surveillance manual and an information system for reporting on E-SISMAL. The informant also stated that the internet network used was often interrupted or not smooth.

The results of the FGD revealed that all officers were able to complete reports at the end of each month by recording on the blanks provided by the Lahat District Health Office. However, malaria health center staff do not understand using E-SISMAL, so they cannot enter data into E-SISMAL.

\section{Process}

The reporting system starts from the level of the midwife in charge of the area (known as penjawi) and the Pustu (sub-health center). The penjawi or pustu collects data every week at the health centers. Every penjawi and practicing doctor who encountered a malaria case sends or refers the patient for laboratory examination to the local community health centers. in charge at the community health center at the end of each month.

Each community health center sends a malaria report and other program reports to the Lahat District Health Office no later than the $5^{\text {th }}$ of the following month. Even though the community health centers have entered data via E-SISMAL, physical reports are still being sent to the Lahat District Health Office. Only then did the Lahat district health office enter data into E-SISMAL and send it to the South Sumatra person in charge, where it proceeded to the Directorate General of Disease Prevention and Control, the Indonesian Ministry of Health. The flow of report submission can be seen in Figure 1. Research in Malawi found that paper-based reports have several weaknesses, requiring proper storage space or being lost or torn ${ }^{10}$.

\section{Output}

Based on the monthly report papers, the information in the health centers was in the form of reports of malaria case data by gender, data on malaria suspects, such that the health center did not create a recapitulation or visualize the data. The health center reports to the Lahat district health office every month. The Lahat District Health Office gave input via meetings, mini-workshops, and visits to health centers. Malaria information is disseminated across sectors and communities every three months or when high malaria cases are discovered. Unfortunately, the conference was canceled because of the COVID-19 outbreak and the presence of visiting health professionals. Problems and obstacles encountered by establishing the WA malaria group.

Then, the data was recapitulated by the malaria person

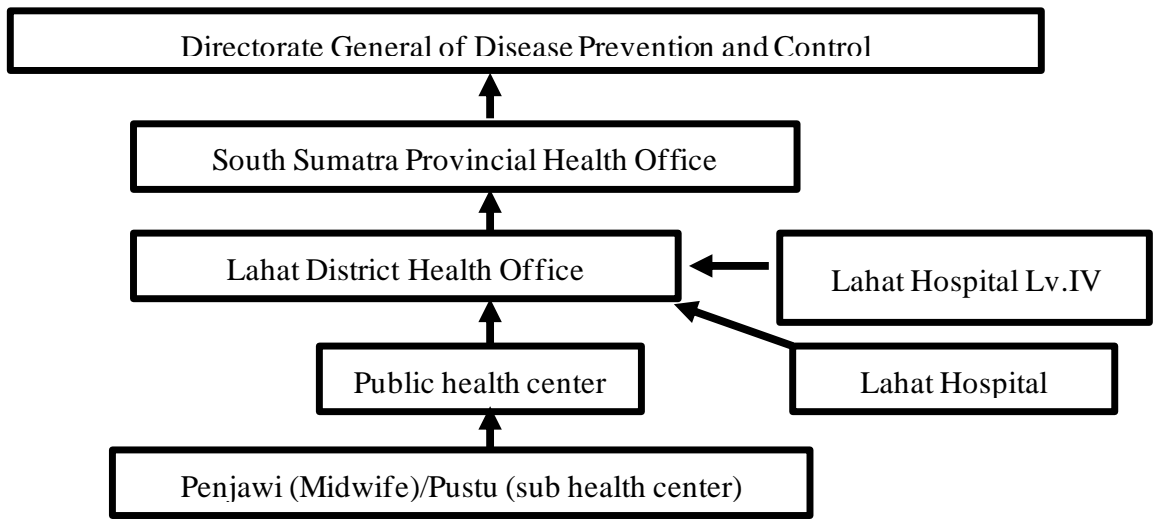

Figure 1. The flow of the lahat district malaria surveillance report submission 


\section{Discussion}

\section{Input}

The human resource who managed the malaria program at the Lahat District Health Office consists of one person. The officer had the dual task of holding more than one program. At the time of conducting PE, the malaria person in charge went down together with the surveillance officer. The management of the malaria program at the community health centers consists of one person each. Based on the malaria management guidelines, the standard for malaria officers at the district health service level is two people with one entomologist and one epidemiologist education; at the community health centers level, one person with an epidemiologist or entomologist education ${ }^{11}$. The study results found that the education of the program person in charge at both the health office and health centers did not meet the standards because no one had an epidemiologist or entomologist educational background. Inadequate educational credentials will result in a lack of awareness among workers concerning malaria monitoring ${ }^{12}$.

Funding for malaria control is sourced from BOK funds. The Health centers propose the RUK to the Lahat Health Office. The approved funds are usually not the same as the proposed ones. Currently, the COVID-19 pandemic has caused a refocusing of the budget at the Lahat District Health Office. Therefore, the plan to conduct training or refresher in 2020 and 2021 could not be carried out. There was no particular funding allocated to handle the malaria reporting system. According to the results of recent research done in the Mekong, the costs associated with malaria monitoring information systems vary depending on the needs, particularly the kind of technology used, which may be a computer or mobile phone acquired privately by the officer who utilizes them for work ${ }^{13}$. Research in South Africa and Madagascar also found that the internet network became a problem for delays in sending reports electronically ${ }^{14}$. To overcome internet network problems, the government needs to embrace the private sector, especially ITC (Information Technology Communication) providers, to form collaborations, such as memorandum of understanding 15 .

There were no clear instructions at the community health centers governing using E-SISMAL and about malaria monitoring. As a consequence, the E-SISMAL malaria monitoring reporting system was subjected to independent study. It is advisable to download from the internet and independently convert the instructions for their specific community health centers.

Most community health centers officers had dual duties as laboratory officers. The officer was still able to complete malaria surveillance with paper-based reporting. The community health centers officers have received E-SISMAL training, but they felt they do not understand how to use E-SISMAL. Coupled with frequent blackouts in one of the community health centers and the internet network not being smooth, this led to reporting through E-SIMAL not being accomplished. Based on the FGD, officers have been receiving E-SISMAL training for a long time, so they require offline retraining on E-SISMAL.

Similar results in a study in the Solomon Islands found that lack of training and refresher16-18, high workload and lack of professional staff could lead to reporting delays ${ }^{19}$. Research in Uganda found an increase in the achievement of indicators for completeness of reports by training malaria officers 20 . The training that can be given to malaria management officers and laboratories includes malaria microscopy, basic entomology training, and mapping of malaria vector breeding using the global positioning system $(\mathrm{GPS})^{21}$.

\section{Process}

Malaria management officers have participated in $\mathrm{E}$ SISMAL training in 2018 and 2019, despite a lack of understanding of using E-SIMAL. Based on the malaria management manual, it is known that the officers' competence influences the success and sustainability of a program ${ }^{11}$. Thus, training that includes offline practice is necessary for officers to understand the systems better. Officers must also get a refresher on basic malaria training, entomologists. In 2020 and 2021, Indonesia will experience a period of the COVID19 pandemic with limited training. 
The FGD's reporting flow conforms with standard norms. Unfortunately, the E-SISMAL could only be utilized for reporting at the district health office level once the input component is fixed. The Lahat District Health Office supports entering data for each community health center's E-SISMAL system, leading to the increased workload of the malaria person in charge. The Lahat District Health Office survey indicators at each health center and analyze the data and visualization (figure 2).

The outputs of the input and process components determine the surveillance indications. The report's completeness shows that all data has been gathered; on the other hand, the report's accuracy suggests that the pace of malaria control has not been maximized. The Lahat district obtains 99.29\% completeness and $36.43 \%$ correctness of reporting in E-SISMAL for 2020. average of $80 \%$, as the WHO has requires ${ }^{22}$. Research in Uganda in Kabarole District showed accuracy report at $32 \%$ and completeness at $63 \%$. The district is less sensitive to detecting diseases with epidemic potential23. Several factors that influence the success of surveillance are cross-sectoral coordination and forging regional partnerships ${ }^{24}$. It aims to collect complete and correct data on malaria cases promptly. Electronic systems reduce report delays, but their implementation requires considerable effort25. Webbased surveillance information systems have been developed in several countries by integrating mobile technology with health data management systems to track malaria cases 26 . In South Sumatra, Androidbased malaria reporting will also be developed to speed up the reporting process ${ }^{27}$.

The report accuracy indicator is still below the national

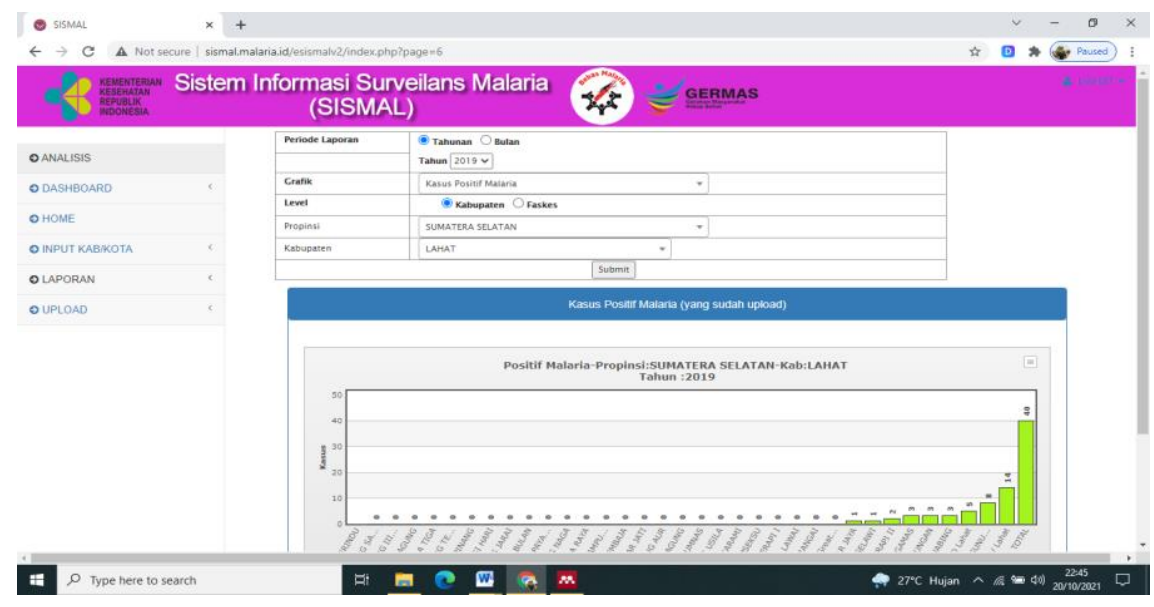

Figure 2. Graphical data visualization on E-SISMAL

\section{Output}

Each data obtained is recapitulated and visualized in tables/graphics and endemicity maps to provide a profile of surveillance that community health centers and the health officials have carried out 28 . Based on FGDs and in-depth interviews, it was found that the community health centers and the Lahat district health officials did not make a malaria risks map. Research in the Surveillance of the Federal Republic of Nigeria found that the representativeness of surveillance data is very useful for determining interventions and measuring to achieve malaria elimination ${ }^{29}$. The district health office and community health facilities provide reports to the public. The provincial health office could examine E-SISMAL data in real-time. In addition to monthly visits to community health institutions, the Lahat District Health Office often conducts interviews with communities.

The study does have some limitations. Respondents may be biased due to online instead of direct observation. Although specific questionnaires are provided, respondents may be confused by the digital application, therefore, miss reply by giving general answers.

\section{Conclusions}

The E-SISMAL malaria monitoring reporting 
initiative was implemented by the Lahat District Health Office. The health center officers ' unable to use ESISMAL, the limitations of the internet network and the absence of guidelines for applying E-SISMAL have impacted reporting delays. The Lahat Health Office should coordinate with telecommunications firms to ensure the network's smooth functioning. Socialization, training, and E-SISMAL practice will help persons in charge to improve their skills. A mobile phone-based malaria surveillance information system and specific E-SISMAL recommendations must be created for the Lahat district.

\section{Acknowledgement}

We would like to thank the Health Department of Lahat Regency for supporting the study. The study was funded by the DIPA of Public Service Agency of Universitas Sriwijaya 2021 (SP DIPA023.17.2.677515/2021), with the Rector's Decree Number of 0010/UN9/SK.LP2M.PT/2021 (on April 28, 2021).

\section{References}

1. Galli A, Đurović G, Hanscom L, Knežević J. Think globally, act locally: Implementing the sustainable development goals in Montenegro. Environ Sci Policy. 2018;84(July 2017):159169. doi:10.1016/j.envsci. 2018; 03: 012

2. Dombrowski JG, de Souza RM, Silva NRM, et al. malaria during pregnancy and newborn outcome in an unstable transmission area in Brazil: A population-based record linkage study. PLoS One. 2018; 13(6): 1-16. doi:10.1371/journal.pone.0199415

3. Indonesian Government. Ministry of Health. Profil Kesehatan Indonesia Tahun 2019; 2020. doi:10.5005/jp/books / 11257_5

4. Indonesian Governement. Ministry of Health. Pedoman Penggunaan Elektronik Sistem Informasi Surveilans Malaria (E-Sismal).; 2013.

5. Astuti EP, Ipa M, Ginanjar A, Wahono T. Upaya Pengendalian Malaria Dalam Rangka PreEliminasi di Kabupaten Garut: Sebuah studi kualitatif. Bul Penelit Sist Kesehat. 2019; 22(4): 255-264. doi:10.22435/hsr.v22i4.1761

6. Baloyi RE, Shandukani MB, Graffy R, et al. Evaluating a 24-h mobile reporting system for malaria notifications in comparison with a paper-based system in South Africa, 2015. Malar J. 2018; $17(1)$ : 1-10. doi: 10.1186/s 12936-018-2451-x

7. Hasyim H, Firdaus F, Prabawa A, et al. Potential for a web-based management information system to improve malaria control: An exploratory study in the Lahat District, South Sumatra Province, Indonesia. PLoS One. 2020; 15(6): 1-13. doi:10.1371/journal.pone.0229838

8. Win Han Oo, Win Htike, Cutts JC, et al. A mobile phone application for malaria casebased reporting to advance malaria surveillance in Myanmar: a mixed methods evaluation. Malar J. 2021; 20(1): 1-14. doi:10.1186/s 12936-021-03701-6

9. Ahmad L, Munawir M. Sistem Informasi Manajemen.; 2002.

10. Tizifa TA, Nkhono W, Mtengula S, van Vugt M, Munn Z, Kabaghe AN. Leveraging phone-based mobile technology to improve data quality at health facilities in rural Malawi: a best practice project. Malar J. 2021; 20(1): 203. doi: 10.1186/s 12936-021-03742-x

11. Direktur Jenderal P2PL KKRI. Pedoman Manajemen Malaria. Buku Pedoman. Published online 2014: 1-150. http://ppiddinkes.sumselprov.go.id/download/107

12. Wayan Sri Widyantari N, Pasek Kardiwinata M, Luh Putu Suariyani N. Evaluasi surveilans demam berdarah dengue di Kabupaten Bangli tahun 2017. Arch Community Heal. 2018; 5(1): 33-42.

13. Levin A, Potter R, Tesfazghi K, et al. Costing electronic private sector malaria surveillance in the Greater Mekong Subregion. Malar J. 2021; 20(1): 1-12. doi:10.1186/s 12936-021-03727$\mathrm{w}$

14. Randriamiarana R, Raminosoa G, Vonjitsara $\mathrm{N}$, et al. Evaluation of the reinforced integrated disease surveillance and response strategy using short message service data transmission in two southern regions of Madagascar, 201415. BMC Health Serv Res. 2018; 18(1): 1-13. doi:10.1186/s 12913-018-3081-2

15. Prisanda E, Febrina R. Penerapan Teknologi Informasi Dan Komunikai Berbasi Aplikasi SISPEDAL Dalam Rangka Mewujudkan Good Village Governance. J Gov Innov. 2019; 1(1): 154-170.

16. Chehab MA, Bala MO, Al-Dahshan A, et al. Evaluation of the Completeness and Timeliness of National Malaria Surveillance System in Qatar, 2016. Cureus. 2018; 10(6): e2851. doi: 10.7759/cureus.2851

17. Davies C, Graffy R, Shandukani M, et al. Effectiveness of 24-h mobile reporting tool during a malaria outbreak in Mpumalanga Province, South Africa. Malar J. 2019; 18(1): 19. doi:10.1186/s 12936-019-2683-4 
18. Hannah H, Brezak A, Hu A, et al. Field-based evaluation of malaria outbreak detection and response in Mudzi and Goromonzi districts, Zimbabwe-2017. Glob Public Health. 2019; 14(12): 1898-1910. doi:10.1080/17441692.2019.1642367

19. Wangdi K, Sarma H, Leaburi J, McBryde E, Clements ACA. Evaluation of the malaria reporting system supported by the District Health Information System 2 in Solomon Islands. Malar J. 2020; 19(1): 1-22. doi:10.1186/s 12936-020-03442-y

20. Westercamp N, Staedke SG, Maiteki-Sebuguzi $\mathrm{C}$, et al. Effectiveness of in-service training plus the collaborative improvement strategy on the quality of routine malaria surveillance data: results of a pilot study in Kayunga District, Uganda. Malar J. 2021; 20(1): 1-12. doi:10.1186/s 12936-021-03822-y

21. Murhandarwati EH, Kusumasari RA, Purwono $\mathrm{P}$, et al. Pelatihan mikroskopis dan entomologi pada tenaga laboratorium dan entomologis lokal di Kecamatan Kokap untuk mendukung eliminasi malaria di Kabupaten Kulon Progo, DIY. J Community Empower Heal. 2019; 2(1): 72-83. doi: $10.22146 /$ jcoemph.42298

22. World Health Organization (WHO). Joint External Evaluation Tool: International Health Regulations.; 2018.

23. Tumwebaze M, Solomon A, Tukahirwa A, Kamukama S. Strengthening District Health Teams Capacity in Surveillance Systems and Response to Public Health Threats in Western Uganda through Field Epidemiology Training Program (FETP). Open J Epidemiol. 2020;
10(02):

$132-145$.

doi:10.4236/ojepi.2020.102012

24. Lertpiriyasuwat C, Sudathip P, Kitchakarn S, et al. implementation and success factors from Thailand's 1-3-7 surveillance strategy for malaria elimination. Malar J. 2021; 20(1): 201. doi: 10.1186/s 12936-021-03740-Z

25. Swaan C, van den Broek A, Kretzschmar M, Richardus JH. Timeliness of notification systems for infectious diseases: A systematic literature review. PLoS One. 2018; 13(6): 1-19. doi: 10.1371/journal.pone.0198845

26. Fornace KM, Surendra H, Abidin TR, et al. use of mobile technology-based participatory mapping approaches to geolocate health facility attendees for disease surveillance in low resource settings. Int $J$ Health Geogr. 2018; 17(1): 1-10. doi:10.1186/s12942-018-0141-0

27. Hasyim H, Misnaniarti M, Heroza RI, Sunarsih E. Pelatihan E-Sismal Mobile Berbasis Android Bagi Petugas Puskesmas Di Daerah Endemik Malaria. J Pengabdi Sriwij. 2020; 8(4): 1151 1156. doi:10.37061/jps.v8i4.13191

28. Indonesian Government. Ministry of Health. Kementerian Kesehatan RI - 2008 - Keputusan Menteri Kesehatan RI Nomor 275/Menkes/SK/III/2007. Tentang Pedoman Surveilans Malaria. Published 2007. https://persi.or.id/wpcontent/uploads / 2020/11/kmk2752007.pdf

29. Visa TI, Ajumobi O, Bamgboye E, Ajayi IO, Nguku P. Evaluation of malaria surveillance system in Kano State, Nigeria, 2013-2016. Infect Dis Poverty. 2020; 9(1): 1-9. doi:10.1186/s40249-020-0629-2 